\title{
THE EMPLOYMENT RIGHTS AND LEGAL PROTECTION FOR PROFESSIONAL FOOTBALLERS IN MALAYSIAN LABOUR MARKET
}

\author{
Jady@Zaidi Hassim* \\ Universiti Kebangsaan Malaysia \\ Anowar Zahid \\ Universiti Kebangsaan Malaysia
}

\begin{abstract}
This paper discusses the employment rights of professional footballers in general. The issue to be addressed is whether the rights established in the unilateral and standard blueprint of player agreements can be considered fair for both sides. Indent analysis on this jurisdictional issue significantly concerns the standard terms of an employment contract that influence a professional footballer's value in the labour market and player transfer policy. This paper adopts a dual methodology of research, namely quantitative and qualitative research. The quantitative data reflect a considerably high level of understanding of the players of the explicitly stated as well as the merely implied contractual terms. However, the majority of footballers are neither individually nor collectively represented in the bargain deal with the employers, which reveals the need of a proper players' union to transform sports into a labour market which is able to guarantee a stable economic activity. The empowerment of professional sports could generate more marketing revenues and thus enhance human development in professional sports.
\end{abstract}

Keywords: Professional Footballers; Employment Rights; Labour Market; Economic Activity.

\section{INTRODUCTION}

The government recognises the importance of a sports policy as a basis to build and educate the nation (McHenry, 1980) apart from political diplomacy (Macintosh \& Hawes, 1993). In addition to education and politics, an economic analysis needs to be considered if the government aspires to provide a basic but effective legal framework for sports professionalism and the labour market (Scully, 1994). The idea is to protect professional footballers because legal intervention is significantly correlated with sports professionalism, contractual relationships, and to the various legal provisions relating to the employment law and policy (Walter, 2005). Considering that sport is a relatively new industry in Malaysia, the framework of sports policies and laws is still inadequate. Among these inadequacies are for example the sports governance structure on employment contract policy and the level of contractual knowledge among the professional players. Despite written standard agreements between footballers and sport clubs, there exist numerous escape terms to avoid liabilities and obligations. The terms are usually drafted unilaterally and less favourable in the context of employment laws. In order to remedy this situation, a players' union could balance the power and allow the players to negotiate on more equal terms. However, such a remedy is not available at the present since the contractual terms are silent. These silent terms - although not spell out in the player contract - are still operative and protected under

•Corresponding Author: Jady @ Zaidi Bin Hassim, Faculty of Law, Universiti Kebangsaan Malaysia. Tel: (603) 8921-6361. Fax: (603) 8925-3217. E-mail: jady@ukm.edu.my; jadyhashim@gmail.com 
the principle of common law and equity which theoretically binds both parties to ensure justice and fairness. This paper investigates the knowledge footballers have of (1) the unconstructed terms or implied contractual rights in football contracts and (2) a transformation policy in sports unions recognising the potential of professional football as a viable labour market for its stable economic role. The empowerment of professional sports in Malaysia has the potential to generate new marketing revenues and enhance the human development in professional sports.

\section{LITERATURE REVIEW}

In Malaysia, professionalism has evolved from certain economics, politics and aesthetic standards modelled on differences of race, religion and language (Silk, 2002). The commercial value and impact of the global sports industry, especially in terms of image rights, broadcastings, intellectual properties and copyrights have significantly contributed to the rise of sports professionalism in Malaysia (Silk, 2002; Gruneau, 1989).

The implementation of the Malaysian Plan resulted in a total of RM620.8 million being allocated for the development of the sports industry. $51.7 \%$ of this amount has been spent for the upgrading of sports facilities and the realization of development programmes for high performance and professional athletes (RMK 9, 2007). When the plan was first introduced in 1966, a total of RM3.3 million was allocated to build multi-purpose sports infrastructures in order to organise sports activities for the Malaysian youth who made up 66\% of the total population (RMK 1, 1966 -1970). The establishment of the National Sports Council (NSC) regulated all sporting activities of the nation (RMK 2, 1971-1975). Its emphasis was on professional sports. Sport was understood as an asset for the country's international image which was enhanced by organising world class tournaments (RMK 3, 1976-1980). The National Sports Policy 1988 (now NSP 2009) introduced a more systematic structure in the administration of national sports. The involvement of all parties, especially the Olympic Council of Malaysia (OCM) and the National Sports Institute (ISN) indirectly enhanced sports professionalism in the country. As a result, professional sports have become a career choice for footballers.

The history of the professional labour market in Europe and America contains differing legal perspectives. Weatherill (2000) states that the Helsinki Commission Report 1999 treated professional sports in Europe differently compared to the United States. The evolution process of professional sport in Europe only began its rapid development after the European Economic Community Treaty (EEC) in 1957. The agreement was also known as the Rome Treaty and was purely economic-oriented in nature (Craig et al., 2003). Professional sports were not recognised as an economic activity (Den Bogaert, 2005) until the European Court of Justice (ECJ) decided so in the Bosman case (Union Royal Belge des Sociétés de Football association v Jean-Marc Bosman [1995] ECR I 1405). Despite this recognition, the case's verdict has received great opposition, especially by the respective world sports bodies (Weatherill, 1998, Stefaan, 2005). In order to treat professional sports as an economic activity, labour law played an important role in protecting footballers and its league through various collective negotiations and agreements. American sport history serves here as a good illustration. At the early stage, American sports were characterised by the blatant exploitation of footballers and baseball players through an imposed reserve clause (Grayson, 2000). This clause provided more benefits in terms of financial stability for the club and less favourable towards footballers (Robert et al., 1986). However, since the late 1960s American court started to recognise the athletes' rights as employees. American professional players now have bargaining rights to determine several issues regarding their professional career, such as the right for representation (agencies and intermediaries), payment of wages and benefits, 
arbitration, drafting of contracts and even the right to determine the regulations of the game (Robert et al., 1986). Gardiner et al. (2006) asserted that this situation is not accidentally governed by law but assisted by various associations with vested economic interests.

However, the situation is different in Malaysia. Malaysian contract law does not adequately protect professional footballers. Section 38(1) of Malaysian Contract Act 1950 states that "The parties to a contract must either perform, or offer to perform, their respective promises, unless the performance is dispensed with or excused under this Act, or of any other law". This was supported by the Malaysian football case of Hj. Osman Hj. Aroff \& Anor v Abdul Karim Pin [1988] 1 CLJ (Rep) 108, where Syed Agil SCJ emphasised that players must fulfill his obligations under the contract. However, despite the mandatory provision of section 38 of the Contract Act 1950 to perform their contractual obligations, player's contract should be treated differently from ordinary contract. The different nature of player's contract that is standard and fixed-term has dispensed the ordinary contractual relationship. Player's contract has been drafted and regulated privately by internal and autonomous provision of 'Regulation on the Status and Transfer of Players' by the international body of football (The Fédération Internationale de Football Association - FIFA). The private contractual relationship that existed in player's contract is sui-generis and not under the scope of contract law - See Hafizi Roslee v Persatuan Bolasepak Malaysia [2015] 7 MLJ 316. The validity of the standard contract has been challenged in the case of Polygram Records Sdn Bhdv The Search [1994] 3 MLJ 127. The test is not on the protection of the contract law, but whether players who signed the contract knew and voluntarily accepted the consequences of the obligation. Moreover, there exists a measure of uncertainty whether other labour law provisions related to safety (Occupational Safety and Health Act 1994), remuneration (Employment Act 1955), compensation (Workman Compensation Act 1952), dispute resolution (Industrial Relationship Act 1967) and unionism (Trade Union Act 1959) can be applied in order to protect their professional careers.

\section{DATA COLLECTION AND METHODOLOGY}

For this research, data has been collected by circulating questionnaires among Malaysian football players concerning their demographic status, their awareness of the contractual and non-contractual rights and obligations, and their consciousness of the bargaining powers through an orgnisational (union) form. Then, the data have been analysed by using SPSS 16 for means and frequency. In this connection, statutory and case laws have been analysed to determine the level and extent of the protection of the Malaysian football players' rights and to delineate the scope of their obligations. Relevant secondary research materials including books, journal articles, etc have been consulted to support or critique the rights and obligations regime available under Malaysian law and actually enjoyed by the players.

\section{MALAYSIAN FOOTBALLERS' RIGHTS AND OBLIGATIONS}

\subsection{Demographic Data}

A total of 304 Malaysian professional footballers were quantitatively surveyed. The subjects were selected firstly by way of zoning. In this procedure the North Zone included the states of Kedah and Perlis, the South Zone included the states of Johor and Malacca, the East Zone the states of Pahang, Kelantan and Terengganu, the West Zone Pahang and Selangor, the Middle Zone the Federal Territory 
of Kuala Lumpur, governmental agencies of PDRM and ATM, while the football clubs (such as PKNS FC). East Malaysia was represented by Sarawak. As part of the second procedure, players were selected randomly. However, the survey was mostly answered by the majority of the first playing team.

Table 1: The demographics of the Malaysian footballers

\begin{tabular}{lc}
\hline \multicolumn{1}{c}{ Item } & Total Percentage and Frequency \\
\hline Race & \\
Malay & $88.8 \% ; \mathrm{n}=270$ \\
Chinese & $1.3 \% ; \mathrm{n}=4$ \\
Indian & $3.9 \% ; \mathrm{n}=12$ \\
Others & $5.9 \% ; \mathrm{n}=18$ \\
Age & \\
18 years old & $2 \% ; \mathrm{n}=6$ \\
19-25 years old & $74.7 \% ; \mathrm{n}=227$ \\
26-35 years old & $23 \% ; \mathrm{n}=70$ \\
Above 36 years old & $0.3 \% ; \mathrm{n}=1$ \\
Educational Level & \\
SPM & $85.9 \% ; \mathrm{n}=261$ \\
Certificate & $6.6 \% ; \mathrm{n}=20$ \\
Diploma & $4.9 \% ; \mathrm{n}=15$ \\
Graduates & $2.6 \% ; \mathrm{n}=8$ \\
Playing Experience & \\
Less than 1 year & $9.9 \% ; \mathrm{n}=30$ \\
2-4 years & $43.1 \% ; \mathrm{n}=131$ \\
5-7 years & $25 \% ; \mathrm{n}=76$ \\
Above 8 years & $22 \% ; \mathrm{n}=67$ \\
Employment Contract (Term) & \\
1 year & $60.2 \% ; \mathrm{n}=183$ \\
2 years & $16.4 \% ; \mathrm{n}=50$ \\
3 years & $3 \% ; \mathrm{n}=9$ \\
Not sure & $20.4 \% ; \mathrm{n}=62$ \\
Monthly Salary & \\
Less than RM1500 & $41.8 \% ; \mathrm{n}=127$ \\
RM1500-RM5000 & $38.5 \% ; \mathrm{n}=117$ \\
RM5000-RM8000 & $15.1 \% ; \mathrm{n}=46$ \\
Above RM8000 & $4.5 \% ; \mathrm{n}=14$ \\
\hline \hline
\end{tabular}

The state teams (i.e., the Kedah Football Association) refer to teams representing the Malaysian states. The state teams and governmental agencies (ATM and PDRM) are managed by an unincorporated state body under the affiliation of the Football Association of Malaysia (FAM) and registered with the Commissioner of Sports under the Sports Development Act 1997. On the other hand, club teams fall under the management of the sports divisions of corporate bodies registered under the Company Act 1965. Since the activities conducted by the clubs are sports based, they also need to be registered under section 15 of the Act 1997. The numbers of the respondents according to state beginning with West Malaysia were as follows: Kedah Football Association (FA) (21); Perlis FA (24), Johor FA (17); Malacca FA (16); Kelantan FA (22); Terengganu FA (20); Perak FA (16); Pahang FA (19); Selangor FA (21); Kuala Lumpur FA (16). In East Malaysia the respondents were limited to Sarawak FA (25), whereas the numbers in the governmental agencies were limited to PDRM FA (22) and ATM FA (21), and private clubs (football clubs -45 ). 
All respondents were contractually employed by the states and sport clubs and signed the player agreement. However, not all players are legally represented by solicitors $(.6 \%, \mathrm{n}=5)$ or sports agents $(18.4 \%, n=56)$, and $23 \%(n=70)$ were represented by family members and another $56.9 \%(n=173)$ were self-represented. The accumulated survey data were analysed using SPSS 16 for means and frequency.

\subsection{Contractual Rights and Obligations}

According to the information contained in the survey, the status of the footballers is not equal to that of ordinary workers. Their contract has a special dimension depending on additional factors such as popularity, publicity and commercial value. The nature of their contractual relationship is not solely defined by profit amount and salary status but by team victory, national prestige as well as the professional status. This special group of workers should not be denied their exclusive status in terms of rights and legal protection. A footballer who signs a contract shall have the following rights and responsibilities:

(1) He should not only be subjected to more favourable terms of contract but also receives comprehensive protection of employment laws. This includes all standard employment rights as set out in Part XII of the Employment Act 1955 such as rest days, duration of work and safety regulations. There are two crucial instances in which the law fails to protect the footballers. The first applies to termination without notice as provided in section 14(1)(a) of the Employment Act. Despite the fact that termination must be justified with proper investigation and due inquiry, the court needs to look at the overall facts and evaluate whether the termination is just cause and reasonable. The wording of just cause is not defined and thus gives discretionary power to an employer deciding to terminate a non-performing player. The second instance applies to transfer regulations whereby the transfer term stated in the player agreement is not consistent with FIFA Player Status and Transfer Regulations. To ensure any transfer is conducted fairly and voluntarily, the footballer is free to make fair choices of their team and receive appropriate compensation.

(2) Other terms such as matters related to the contract extension options, sports disputes resolution, contractual period and age restrictions are also left to the discretion of the state / sport clubs. From the first day a contract is signed employers are able to control and limit the freedom of professional footballers. However, in Anderson v Adelaide Football Club Ltd (1993) 48 IR 440), the Australian Football League Players Association (AFLPA) successfully argued that collective agreements between unions and employers on all standard terms were protected by the Australian Football League (Dabscheck et al., 2003). This led to the establishment of a Malaysian version of professional footballers' union under the Trade Union Act 1959 and internationally affiliated under Fédération Internationale des Associations de Footballeurs Professionels (FIFPro). The registration of the Association should not be under the control of the sports commissioner under the Sports Development Act 1997. ${ }^{1}$

\subsection{Implied Contractual Duties in the Standard Football Labour Market}

The first important issue here revolves around unconstructed contractual terms in the player agreement. The terms are not spelled out clearly but implied and binding to both parties. The issuance of a general order on a player agreement draft normally incorporates terms relating to taxation, insurance and transfer

\footnotetext{
${ }^{1}$ Section 15 of Sports Development Act (Act 576) requires every sports body shall apply to the Commissioner to be registered under this Act to carry out any sporting activity.
} 
fees. Some key players may also agree to additional terms relating to marketing; promotion and publicity; sponsorship and scholarship (Gardiner et al, 2006) but usually players sign an agreement containing the standard terms. The difference appears on the last page of the Appendix (Player Agreement) which lists the amount of salary; competition benefits, medical and hospitalisation and insurance coverage. Despite the differences, all terms are clearly defined and explained by sports agents and solicitors (intermediaries). Richard et al. (2005) argued that it was within the interventional power of international sports federations (FIFA) and national sports associations (FAM) to recognise equal terms in the player agreement. Thus, players needed merely to identify these terms and avoid contractual breach. However, there are some implied terms which are not spelled out in the player agreement and regularly breached. Players generally end up breaching these terms simply because they are ignorant of this term or have misinterpreted it. The data analysed below reflect the level of the footballers' knowledge of the implied terms of their employment contract.

\subsubsection{Obedience and loyalty}

Footballers must always obey their coach. The data shows a high rate of compliance of $91.1 \%$ of loyalty to the coach. It includes obeying the instructions during training or compliance to game strategies apart from maintaining discipline and proper behaviour. The duty of obedience is exercised by a majority of $87.5 \%$ while only $2 \%$ are not compliant. This may easily occur when footballers are for example requested to play out of position without their consent. Simple instructions such as wearing sponsored jerseys and training places chosen by the employer are considered common instructions but are not necessarily spelled out in detail in the agreement. In respect to the issue of loyalty, footballers cannot provoke or advice others to breach employment contracts (Richard et al, 2005). Loyalty to the club entails obeying instructions from officers of the club, coaches, team doctors and appointed nutrition experts.

\subsubsection{Protecting the club's image}

A total of $93.8 \%$ stated that it is their responsibility to protect the image of their employers. Footballers should not put themselves in conflicting interest such as working part-time (representing) for other employers (team or club) or disclosing confidential information relating to strategies and game play without the latter's permission and knowledge. In player transfer, every footballer is aware of the high transfer fees and higher offers.

\subsubsection{Confidential business information}

This duty still continues even though the footballer has ended his service (Wessex Diaries $v$ Smith (1935) $2 \mathrm{~KB} 80$ ) to preserve integrity and good will. The disputed club may request for sanction for any private matter which is considered as highly confidential. Clubs can manipulate the employment contract to prevent footballers from spreading confidential information even though it is a matter of public interest. Gardiner et al. (2006) stated that there is no specific law that requires the public to be informed about the selection and dismissal of a footballer. If the disclosure is necessary, it should be channeled to limited parties only, such as the governing sports bodies or sports arbitration panels.

\subsubsection{Responsibility to be cautious}

Footballers should always protect themselves from injuries and accidents. The injury inflicted will cause losses to the team and the association. If the injury occurs due to negligence and failure to exercise caution on the part of the footballer himself, the employer is entitled to claim damages. 


\subsubsection{Improve the professional status}

This term requires footballers to train and continue developing new playing skills to remain internationally competitive. According to Cresswell v Board of Inland Revenue [1984] IRLR 190, employers need to provide intensive training and are expected to conduct research to improve their players' fitness and performance level. Footballers are expected to adapt to new training methods. It is considered a breach of contract if a footballer pretends to be unfit or injured so as to collaborate with a new club to transfer them paying lower transfer fees.

The legal understanding on implied terms which is not spelled out in the standard player agreement is illustrated in Table 2. The summarised data show that Malaysian footballers are able to contribute despite the non-existence of these terms. Footballers are expected to fulfil the obligation without failure.

Table 2: Duties of Professional Footballers

\begin{tabular}{|c|c|c|c|c|c|}
\hline Code & Question & Yes & No & Not Sure & Awareness \\
\hline K5 & $\begin{array}{l}\text { Do you understand your duties and } \\
\text { responsibilities as a professional footballer? }\end{array}$ & $92.8 \% ; n=282$ & $1.6 \% ; n=5$ & $5.6 \% ; n=17$ & Very High \\
\hline $\mathrm{K} 23$ & $\begin{array}{l}\text { Do you comply with the instructions and } \\
\text { regulations of the football association? }\end{array}$ & $87.5 \% ; n=266$ & $2 \% ; n=6$ & $10.5 \% ; n=32$ & High \\
\hline $\mathrm{K} 22$ & $\begin{array}{l}\text { Are you under the instruction/control of the } \\
\text { coach while you are playing? }\end{array}$ & $91.1 \% ; n=277$ & $4.6 \% ; n=14$ & $4.3 \% ; n=13$ & Very High \\
\hline $\mathrm{K} 24$ & $\begin{array}{l}\text { Are you required to protect the image of your } \\
\text { association? }\end{array}$ & $93.8 \% ; n=285$ & $2.3 \% ; n=7$ & $3.9 \% ; n=12$ & Very High \\
\hline $\mathrm{K} 25$ & Do you respect your association? & $94.1 \% ; n=286$ & $2 \% ; n=6$ & $3.9 \% ; n=12$ & Very High \\
\hline
\end{tabular}

\section{EMPLOYER'S ROLE IN EXECUTING PLAYER CONTRACTUAL POLICY}

Sports clubs (team) also have duties and responsibilities to their players. The first obligation is to provide work (training and competition) to players. As the nature of work in a sports employment contract is quite different from other occupations, players must be ready and willing to perform work only when requested by the club. The club must provide clear instructions which are consistent with the player's status and playing position. Excessive work instructions must be avoided as the work clause can be declared null due to freedom limitations (Richard et al, 2005). The employment policy needs to consider these clauses to ensure the contractual stability of the professional labour market:

(1) Accurate salary schedules. Footballers should receive their salaries strictly according to the agreed contractual schedule. Salary has been interpreted by the Employment Act 1955 as basic salary and all other cash payments to an employee for the work done under contract of employment excluding bonus, allowances and bonus. The salary amount and payment mode must be clearly stipulated in the contract, and any failure to observe this term or unreasonable delay is considered as a breach on the part of the employee. The data show that only $44.4 \%(n=135)$ of the clubs, especially private sports clubs, pay wages according to schedule while almost half that is $39.8 \%(n=121)$ of the players do not receive their salary on time.

(2) Injury and health issues. The question of salary sometimes correlates with injury or with footballers failing to perform their duties. In Mears $v$ Safecar Security Limited [1982] 2 All ER 865 , the court explicitly stated that employers are obligated to pay wages to sick or injured employees. The footballers as well as the employer must at any reasonable time observe health 
and safety levels. Footballers are expected to minimise injury risks and avoid practising too hard and employers must ensure a high level of safety of the playing environment (facilities and competition). If these two aspects are affected, it indirectly reduces capability and increases various medical and legal costs. The data showed that not all sport clubs are providing good medical facilities. Of the surveyed footballers, only $67.8 \%$ agreed that their masters were providing adequate services in that aspect while $17.8 \%$ disagreed and $14.5 \%$ were uncertain. A failure to provide these facilities causes the employers to be guilty under the Occupational Safety and Health Act 1994 (OSHA).

(3) Respect the professional status of footballers. Some sport clubs draft the player contract unilaterally and less favourable. The failure to respect the footballers' professionalism may cause these clubs' reputations to be tarnished and lose support. For example, to ensure the rights of footballers, sport clubs have the obligation to provide procedures for arbitration and mediation regarding disciplinary offenses and misconduct. Sport clubs must provide the footballers with opportunities to raise objections or complaints and all the dissatisfactions should be heard as fairly as possible. The study showed that not all footballers are provided with knowledge regarding arbitration and complaints procedures. Only $10.2 \%$ of them understood and were briefed on the hearing process implemented at the domestic level. A total of $84.9 \%$ of footballers who were ignorant of these matters clearly shows the need for a more effective, transparent and voluntary mechanism.

\section{THE FOOTBALLERS' UNION: STRENGHTENING THE LABOUR MARKET}

This paper examines the suggested establishment of a players' union. A union would be able to recognise the potential of professional football as a new labour market that constitutes stable economic activity. The Professional Footballers' Association of Malaysia (PFAM) functions as a platform for the footballers' welfare and demands and negotiates a balanced relationship between footballers and sports clubs. The existence of a union is to be regarded a necessity development because only a union is able to act as an intermediary in many issues relating to sports. Such a union would require the cooperation of all footballers to create a sport that attracts more supporters and maximises profits. According to Neale (1964), a sports league needs to maximise the uncertainty of results in a match to generate the enthusiasm of fans and supporters. Its rationale is that each team has its financial strength and popularity. Rich teams are certainly able to attract high profile players who can win the matches for them. Less affluent and smaller teams, on the other hand, find it very difficult to contract talented players due to their limited financial resources. The PFAM plays the role of balancing this situation by preparing and dividing equal distribution of contract opportunities to all professional footballers. Although it can be disputed that this particular strategy is subject to restraint of trade, the alliances between PFAM and sports clubs can create higher salaries and better contractual standard terms.

The PFAM has the authority to represent footballers in conflicts and issues relating to employment or various conflicts in the sports industry. The establishment of the Premier Football League since 1989 and the Super Football League in Malaysia since 2004 are evidence of the existence of regular leagues and playing seasons that require the footballers to serve as professionals. This development should be augmented by more competitive salaries due to the short term nature of their employment contracts, the commercial value of public sports and the rising broadcasting fees. When a footballer signs a sports contract, he is subjected to the terms and conditions of the agreement, regulations, club constitutions, tournaments and matches. The significant constraint of the contract is part of the club's power to prevent 
the footballer from playing for other teams during the duration of contract. The choice of either to continue or terminate a contract allows sport clubs to search for better players, thus denying the existing footballers their right for better contracts. Some clubs send their footballers for training abroad (Berry et al., 1986) which may cause conflicts between footballers and the league organisers. The PFAM can resolve such a conflict and offer a collective bargaining agreement to the mutual benefit of both parties.

Table 3: The significance of the PFA among Malaysian professional footballers (\%)

\begin{tabular}{clcccc}
\hline \hline Code & \multicolumn{1}{c}{ Items } & Yes & No & Unsure & Awareness \\
\hline TU1 & Have you heard of the Players' Union? & 53.6 & 17.1 & 29.3 & Medium \\
TU2 & $\begin{array}{l}\text { Do you know the function of Players' Union? } \\
\text { TU3 }\end{array}$ & 36.5 & 24 & 39.5 & Low \\
& $\begin{array}{l}\text { Do you know the Players' Union's role in } \\
\text { counterbalancing the employer's power? }\end{array}$ & 32.2 & 24.3 & 43.4 & Low \\
TU4 & $\begin{array}{l}\text { Do you know that the Players' Union can negotiate } \\
\text { with the Club and protect the interest and welfare of } \\
\text { professional footballers? }\end{array}$ & 46.7 & 20.7 & 32.6 & Low \\
\hline \hline
\end{tabular}

The study demonstrates the significance of a PFAM as a union which can strengthen the football labour market. In TU1, only 53.6\% ( $\mathrm{n}=163)$ of professional footballers in Malaysia have heard of the existence of the PFA. The remaining of $17.1 \%(n=52)$ have not heard of it while another $29.3 \%(n=89)$ are not sure. The idea to create a PFA was born in recent years in the form of a proposal to register such a PFAM under the Office of Sports Commissioner (Sports Development Act 1997). Footballers have never been informed that they possessed the right to form their own union. Knowledge of membership and the nature of unions were reportedly acquired during informal talks with coaches. For young footballers, the lack of knowledge on unionism is a great loss because their employment contract will determine the greater part of their future.

TU2 and TU3 analysed the footballers' understanding of the functions and roles of the PFA. In TU2, only $n=111$ out of $n=304$ footballers know the function of the PFA. That number represents only $36.5 \%$ of the total overall percentage. The PFA functions to safeguard their welfare and interest, yet most footballers are ignorant of how the PFA would be able to represent and negotiate on their behalf. The PFA would be able to negotiate and bargain collectively and fairly due to the balance of bargaining powers. However, the reality is showed in TU3. Only $32.2 \%(n=98)$ know that the PFA would be able to counterbalance the power of employers (sport clubs). On the other hand, $24.3 \%(\mathrm{n}=74)$ do not know that the PFA could bargain on their behalf. A total of $43.4 \%(n=132)$ are also unsure of the PFA's ability to offset the power of the employers.

The failure to recognise the importance of a footballers' union undoubtedly affects the success of collective negotiation and collective agreement between the sports clubs and the PFA. This failure hinders all existing efforts to upgrade the status of footballers and thus surreptitiously defeats the idea of protecting the rights of footballers in employment contracts. There are two external factors responsible for this situation. Firstly, a national association such as the Football Association of Malaysia (FAM) decided to intervene. The PFAM should be managed independently and without having profitability interest. If the PFAM falls under the management of the FAM, there is clear conflict of interest between the professional footballers and the employers as members of the FAM. The FAM is known for having the tendency to favour employers which can be explained by their interest as members. Secondly, the government may also decide to intervene. According to the survey, a total of $80.3 \%$ ( $n=244)$ out of $n=304$ footballers agreed that the PFAM should be free of political elements and not be represented by politicians. Although it cannot be denied that financial allocations for sports fall 
under the central government budget, that does not mean that the government has autonomous power over the management of the sports association and union. The control over activities and sports development through the Sports Development Act 1997 should not be applied to the activities conducted by the PFA but fall under the jurisdiction of Trade Union Act 1959 and other labour law provisions.

The study examined the general knowledge professional footballers have on respect to the terms of the employment contract as drafted in the player agreement. This understanding is correlated with the respective employment policy adopted by the sports club. The question of whether the constructed terms have achieved the conscionable bargain between footballers and sports club can only be successfully answered though unionism. In spite of the generally high level of awareness of implied terms and hidden elements, contractual breaches of player agreement continue. As such, the success of the professional football labour market depends on the collective power of a union.

\section{CONCLUSION}

In conclusion, the laws governing sports employment are not only based on the Contract Act but include provisions in labour laws. The claim that the labour laws in Malaysia are still not adequate and effective to protect a newly growing profession such as football may be wrong due to the finding that the footballers themselves are not aware of their union rights. The study not only suggests the re-evaluation of unilaterally drafted player agreements in terms of employment freedom and contractual relationship but also an additional policy with respect to any potential intervention from the national sports association (FAM) and government. The findings strongly recommend that Malaysian footballers register as members of the Footballers' Union (PFAM) and decide to be represented by the union in order to be offered more favourable contracts. The union's power to represent its members is well structured and recognised worldwide and indeed is able to protect the rights of the footballers most effectively.

\section{ACKNOWLEDGEMENT}

The authors would like to thank the Malaysian Ministry of Higher Education - Sport Grant (Penyelidikan Dana KSTI UU/001/2008) and FRGS/2/2013/SSI10/UKM/02/1. However, all the contents in this paper are of the authors' responsibility.

\section{REFERENCES}

Berry R. \& Wong, G. (1986). Law and business of the sports industries. Dover MA: Auburn House.

Craig P., \& de Búrca, G. (2003). EU law: Text, cases and materials. ( $3^{\text {rd }}$ Ed.) Oxford: Oxford University Press.

Cresswell v Board of Inland Revenue [1984] IRLR 190

Dabscheck, B., \& Opie, H. (2003). Legal regulation of sporting labour markets. Australian Jurnal of Labour Law, 16, 1-25.

Den Bogaert, S. V. (2005). Practical regulation of the mobility of sportsmen in the EU post Bosman. Nertherland: Kluwer Law International.

Employment Act 1955 
Gardiner, S., James, M., O’Leary, J., Welch, R., Blackshaw, I., Boyes C., \& Caiger, A. (2006). Sports law. ( $3^{\text {rd }}$ Ed.). Great Britain: Cavendish Publishing.

Grayson, E. (2000). Sport and the law. ( $3^{\text {rd }}$ Ed.) London: Butterworths.

Gruneau, R. (1989). Making spectacle: a case study in televised sport production. In L. Wenner (Eds.), Media, Sports and Society (pp. 134-156). Newbury Park, CA: Sage Publications.

Hafizi Roslee v Persatuan Bolasepak Malaysia [2015] 7 MLJ 316

Hj. Osman Hj. Aroff \& Anorv Abdul Karim Pin [1988] 1 CLJ (Rep) 108

Industrial Relationship Act 1967

Macintosh, D., \& Hawes, M. (1993). Sport and Canadian diplomacy. Kingston, Ontario: McGill Queen's University Press.

McHenry, D. E. (1980). The use of sports in policy implementation: the case of Tanzania. Journal of Modern African Studies, 18(2), 237-256.

Mears v Safecar Security Limited [1982] 2 All ER 865

Neale, W. (1964). The peculiar economics of professional team sports: a contribution to the theory of the firm in sporting competition and in market competition. The Quarterly Journal of Economics, $78(2), 1-14$.

Occupational Safety and Health Act 1994

Polygram Records Sdn Bhdv The Search [1994] 3 MLJ 127

Rancangan Malaysia Kedua RMK2. (1971-1975). Kuala Lumpur: Government Printer.

Rancangan Malaysia Kesembilan RMK9 (2006-2010). Putrajaya: Jabatan Perdana Menteri.

Rancangan Malaysia Ketiga RMK3 (1976-1980). Kuala Lumpur: National Printing Department.

Rancangan Malaysia Pertama RMK1 (1966-1970). Kuala Lumpur: Jabatan Chetak Negara.

Richard, V., Clive L., \& Peter, M. (2005). Sports business. (2 ${ }^{\text {nd }}$ Ed.). Great Britain: Jordan Publishing.

Robert, C., Gould, B., \& Staudohar, D. P. (1986). Labor relations in professional sports. USA: Greenwood Publishing Group.

Scully, G. W. (1994). Discrimination: the case of baseball. In G. N. Roger (Eds.), Government and sports business (pp. 221-273). Washington: Brookings Institution.

Silk, M. (2002). Bangsa Malaysia: global sport, the city and the mediated refurbishment of local identities. Media, Culture and Society, 24(6), 775 -794.

Sports Development Act 1997

Stefaan, D. B. (2005). Practical regulation of the mobility of sportsmen in the EU Post Bosman. The Hague: Kluwer Law International.

Trade Union Act 1959

Union Royal Belge des Sociétés de Football association v Jean-Marc Bosman [1995]

Walter, T. C. (2005). Sports law: Cases, Documents and Materials. NY: Aspen Publishers.

Weatherill, S. (1998). Do sporting association make law or are they merely subject to it? European Business Law Review, 9, 217-220.

Weatherill, S. (2000). Resisting the pressures of Americanisation: the influence of European Community law on the European sport model. In S. Greenfield \& G. Osborn (Eds.), Law and sport in contemporary society (pp. 155-173). London: Frank Cass Publishing.

Wessex Diaries v Smith (1935) 2 KB 80

Workman Compensation Act 1952 